\title{
PENGARUH MODEL NUMBERED HEAD TOGETHER TERHADAP AKTIVITAS BELAJAR PENDIDIKAN KEWARGANEGARAAN
}

\author{
Shinta Dewi Rosyanti ${ }^{1}$, Fransisco Adam $^{2}$, Yulita ${ }^{3}$ \\ ${ }^{1}$ Mahasiswa Lulusan Program Studi PGSD Tahun 2019 \\ ${ }^{2,3}$ Dosen STKIP Melawi (Kampus Entikong) \\ Jln. Kuari Yayasan Lintas Batas Kecamatan Entikong Kabupaten Sanggau \\ shintadewir91@gmail.com, adamtp84@gmail.com, buyulita79@gmail.com
}

\begin{abstract}
This research aims to determine the effect of using the Numbered Head Together model on student learning activities in citizenship education in the third-grade students of SDN 01 Noyan. The research method used was a pre-experiment design with the research design used was one group pretest and posttest design. The data analyzed in this research are student learning activities before and after using the Numbered Head Together model. The results of pretest and posttest data analysis on student learning activities in citizenship education, it obtained that the pretest results was $52,81 \%$ with good categories, and the posttest results in ware $76,33 \%$ with very good categories. The results of the research showed a value difference between pretest and posttest of $23,43 \%$. While the results of the hypothesis test are obtained t-count it 2,670 > t-table 2,064 then Ho is rejected and $\mathrm{Ha}$ is accepted, meaning that there is the influence pf the Numbered Head Together model on learning activities for citizenship education.
\end{abstract}

Keywords: Numbered Head Together, Learning Activities.

\begin{abstract}
Abstrak: Penelitian ini bertujuan untuk mengetahui pengaruh penggunaan model Numbere d Head Together terhadap aktivitas belajar siswa pada pendidikan kewarganegaraan di kelas III SDN 01 noyan. Metode penelitian yang digunakan adalah pre eksperiment design dengan rancangan penelitian yang digunakan adalah one group pretest posttest design. Data yang dianalisis dalam penelitian ini adalah aktivitas belajar siswa sebelum (pretest) dan sesudah (posttest) menggunakan model Numbered Head Together. Hasil analisis data pretest dan posttest terhadap aktivitas belajar siswa pada pendidikan kewarganegaraan diperoleh hasil pretest $52,81 \%$ dengan kategori baik, dan hasil posttest $76,25 \%$ dengan kategori sangat baik. Hasil penelitian tersebut menunjukan adanya selisih nilai antara pretest dan posttest 23,43\%. Sedangkan hasil uji hipotesis didapat thitung 2,670> ttabel 2,064 maka H0 ditolak dan Ha diterima artinya ada pengaruh model Numbered Head Together terhadap aktivitas belajar pendidikan kewarganegaraan
\end{abstract}

Kata kunci: Numbered Head Together, Aktivitas Belajar 
Dendidikan kewarganegaraan
sebagai mata pelajaran di Sekolah Dasar menjadi sarana untuk mengembangkan nilai-nilai luhur dan moral berdasarkan budaya bangsa Indonesia. Nilai-nilai luhur dan moral tersebut diharapkan dapat diwujudkan dalam bentuk perilaku dalam kehidupan sehari-hari, sebagai individu maupun anggota masyarakat dan makhluk ciptaan Tuhan Yang Maha Esa. Sehingga, pendidikan kewarganegaraan menjadi mata pelajaran yang penting diajarkan pada jenjang pendidikan sekolah dasar.

Sebagai tenaga profesional, guru merupakan pintu gerbang inovasi yang memegang peranan penting dalam proses pembelajaran. Sehingga seorang guru perlu merancang strategi dalam mengelola pembelajaran agar mampu menciptakan suasana belajar yang menyenangkan dan dapat menumbuhkan aktivitas belajar siswa melalui penggunaan metode, model, dan atau media pembelajaran yang sesuai dengan kebutuhan siswa. Surpijono (2013: x) mengemukakan bahwa suatu pembelajaran harus mampu menciptakan proses belajar yang dapat menumbuhkan suasana yang menyenangkan sehingga peserta didik lebih aktif bertanya, mempertanyakan, dan mengemukakan gagasan. Karena belajar merupakan proses aktif dari si pembelajar dalam membangun pengetahuannya, bukan proses pasif yang hanya menerima kucuran ceramah guru tentang pengetahuan. Hal tersebut menunjukan bahwa belajar adalah proses aktif dari peserta didik dan penggunaan metode, model, dan atau media pembelajaran yang tepat diharapkan dapat meningkatkan aktivitas dan prestasi belajar siswa.

Melalui wawancara yang dilakukan 24 september 2018 dengan wali kelas III, ditemukan bahwa kurangnya pengetahuan guru tentang model-model pembelajaran inovatif khususnya model pembelajaran kooperatif. Hal itu dapat mempengaruhi proses pembelajaran di kelas. Pembelajaran berpusat ke guru.Selain itu penggunaan media pembelajaran masih sangat kurang, hal itu dikarenakan keterbatasan fasilitas yang ada di sekolah.Khususnya media pembelajaran pada pendidikan kewarganegaraan, sehingga pembelajaran hanya bertumpu pada buku pegangan guru.Sedangkan melalui pengamatan langsung yang dilakukan pada saat proses belajar mengajar di kelas, ditemukan bahwa 
aktivitas belajar siswa masih sangat rendah. Hal ini dikarenakan pengelolaan kelas yang kurang baik, kelas menjadi tidak kondusif karena pembelajaran yang kurang menarik dan menyenangkan.

Salah satu model pembelajaran yang dapat dikembangkan dalam upaya untuk meningkatkan aktivitas belajar siswa yaitu dengan model pembelajaran kooperatif tipe Numbered Head Together. Model pembelajaran ini mengutamakan aktivitas siswa dalam mencari, mengolah, dan melaporkan informasi dari berbagai sumber yang nantinya akan dipresentasikan di depan kelas. Sehingga dengan penggunaan model ini dapat menjadikan siswa lebih aktif dan kreatif dalam proses pembelajaran.

Berdasarkan uraian tersebut, peneliti ingin mengadakan penelitian yang berkenaan dengan penggunaan model Numbered Head Together dan pengaruhnya terhadap aktivitas belajar siswa.Oleh karena itu peneliti perlu melakukan suatu penelitian mengenai "Pengaruh Model Numbered Head Together Terhadap Aktivitas Belajar Pendidikan Kewarganegaraan Siswa Kelas III SD Negeri 01 Noyan”.

Tujuan dalam penelitian ini adalah untuk mengetahui aktivitas belajar siswa sebelum dan sesudah menggunakan model Numbered Head Together pada pembelajaran pendidikan kewarganegaraan, serta untuk mengetahui pengaruh model Numbered Head Together terhadap aktivitas belajar siswa pada pendidikan kewarganegaraan.

Pembelajaran dengan model Numbered Head Together diawali dengan pembentukan kelompok kecil yang terdiri dari 4-5 orang dan pemberian nomor kepala. Model ini dikembangka untuk melibatkan lebih banyak siswa dalam menelaah materi dalam suatu pembelajaran dan mengecek pemahaman siswa terhadap isi pelajaran tersebut. Model ini memberikan kesempatan pada siswa untuk saling memberikan idea atau pendapat, mendorong siswa untuk meningkatkan kerja sama dalam kelompok. Model pembelajran ini lebih mengutamakan pada aktivitas siswa dalam mencari, mengolah, dan melaporkan informasi dari berbagai sumber yang nantinya akan dipresentasikan.

Langkah-langkah model Numbered Head Together menurut Trianto (2011, 82-83) yaitu; 1) fase 1: penomoran. Membagi siswa kedalam kelompok kecil terdiri dari 3-5 orang 
dan memberikan nomor kepala kepada setiap anggota kelompok dengan nomor urut 1-5; 2) Fase 2: Mengajukan pertanyaan. Guru mengajukan sebuah pertanyaan kepada siswa. Pertanyaan dapt bervariasi. Pertanyaan dapat amat spesifik dan dalam bentuk kalimat tanya atau kalimat arahan; 3) Fase 3: Berpikir bersama. Siswa menyatukan pendapatnya terhadap jawaban dari pertanyaan yang diberikan guru, dan meyakinkan setiap anggota dalam timnya mengetahui jawaban kelompoknya; 4) Fase 4: Menjawab. Guru memanggil suatu nomor tertentu, kemudian siswa yang nomornya sesuai mengacungkan tangannya dan menjawab pertanyaan untuk selutuh kelas.

Kelebihan model Numbered Head Together menurut Ezi (2014: 4) yaitu ; 1) menyebabkan siswa lebih aktif dalam menjawab pertanyaan; 2) melatih siswa berani dalam menyampaikan pendapar dan berani bicara didepan kelas; 3) motivasi belajar siswa meningkat; 4) melatih siswa bekerja sama dan menghargai pendapat teman dalam kelompok. Sedangkan kelemahan model Numbered Head Together menurut kagen (dalam Ezi, 2014: 4) yaitu; 1) kemungkinan nomor yang sudah dipanggil pendidikan akan dipanggil lagi; 2) tidak semua kelompok akan dipanggil oleh pendidik.

Belajar menurut Gagne (dalam Suprijono, 2013: 2) merupakan "perubahan disposisi atau kemampuan yang dicapai seseorang melalui aktivitas". Perubahan disposisi tersebut bukan diperoleh langsung dari proses pertumbuhan seseorang secara alamiah. Aktivitas yang dimaksud adalah aktivitas siswa dalam proses pembelajaran.

Menurut Suprijono (2013: x) pembelajaran itu harus mampu menumbuhkan suasana sedemikian rupa sehingga peserta didik aktif bertanya, mempertanyaakan, dan mengemukakan gagasan. Karena belajar merupakan proses aktif dari si pembelajar dalam membangun pengetahuannya bukan proses pasif yang hanya menerima kucuran ceramah guru tentang pengetahuan. Pembelajaran aktif adalah proses belajar yang menumbuhkan dinamika belajar bagi peserta didik.

Aktivitas belajar adalah kegiatan yang menuntut keaktifan siswa dalam mendapatkan pengetahuan untuk menghasilkan perubahan tingkah laku berdasarkan kemampuannya 
memahami lingkungan sekitar. menganalisis, mengambil keputusan; Pembelajaran aktif dan efektif diperlukan agar aktivitas siswa meningkat dan pembelajaran menjadi bermanfaat dan bermakna.

Menurut D. Diedrich (dalam Hamalik, 2017: 172) terdapat delapan kelompok kegiatan belajar siswa sebagai berikut; 1) Aktivitas visual, seperti membaca, melihat gambargambar, mengamati demonstrasi, pameran atau mengamati orang lain; 2) Aktivitas lisan, menghubungkan suatu kejadian, mengajukan pertanyaan, memberi saran, mengemukakan pendapat, wawancara, diskusi, dan interupsi; 3) Aktivitas mendengarkan, seperti mendengarkan penyajian bahan/materi ajar, mendengarkan percakapan atau diskusi kelompok, mendengarkan suatu diskusi; 4) Aktivitas menulis, seperti menulis cerita, menulis laporan, memeriksa karangan, membuat rangkuman mengerjakan tes, dan mengisi angket; 5) Aktivitas menggambar, seperti menggambar, membuat grafik, peta, diagram; 6) Aktivitas motorik, seperti melakukan percobaan, melaksanakan pameran, membuat model, menyekenggarakan pameran, menari dan berkebun; 7) Aktivitas mental, seperti mengingat, memecahkan soal,

8) Aktivitas emosional, seperti menaruh minta, gembira, merasa bosan, berani, tenang, gugup.

\section{METODE PENELITIAN}

Penelitian ini dilaksankan melalui penelitian eksperimen dengan metode penelitian adalah pre eksperiment design.Eksperimen ini belum termasuk eksperimen sesungguhnya. Sugiono (2013: 109) menyebutkan bahwa pre-eksperiment design belum merupakan eksperimen sungguh-sungguh. Hal itu karena tidak adanya variabel kontrol, dan sampel tidak dipilih secara acak.Desain penelitian yang digunakan adalah one group pretest-posttest design. Dalam desain ini tidak terdapat kelas control dan hanya kelas eksperimen yang nantinya akan diberikan pretest dan posttest.Pretest dan posttest digunakan untuk membanding keadaan sebelum dan dan sesudah diberi perlakuan atau treatment.

Pengumpulan data merupakan hal yang sangat penting dalam suatu penelitian, karena data-data yang dikumpulkan akan digunakan untuk menjawab rumusan masalah yang diteliti dan menguji hipotesis yang telah dibuat. Teknik pengumpulan data dalam penelitian ini melalui observasi 
dan dokumentasi.Observasi dilakukan dengan menggunakan lembar observasi yang telah dibuat dan divalidasi. Lembar observasi ini dilakukan untuk mengetahui kemampuan mengajar penulis sebagai guru dan aktivitas belajar siswa pada pendidikan kewarganegaraan dalam materi mengamalkan nilai-nilai sumpah pemuda sebelum dan sesudah diberi perlakuan menggunakan model Numbered Head Together. Sedangkan dokumentasi yang digunakan berupa data, gambar berupa foto, dan dokumentasi lain yang mendukung terkait penelitian ini.

Proses analisis data dilakukan setelah data hasil penelitian diperoleh. Hasil analisis data digunakan untuk menjawab rumusan masalah dan hipotesis yang telah dibuat.

Untuk menjawab rumusan masalah satu dan dua, dan untuk menghitung analisis data kemampuang mengajar peneliti sebagai guru yaitu dengan rumus persentase. Penilaian persentase dihitung menggunakan rumus purwanto sebagai berikut (dalam Nurpratiwi, 2017: 4):

$$
\mathrm{S}=\frac{R}{N} \times 100 \%
$$

Keterangan:

$\mathrm{S} \quad$ : nilai persen yang dicari
$\mathrm{R} \quad$ : jumlah skor yang didapatN : skor maksimum

Tabel 1. Kriteria penilaian

\begin{tabular}{|c|c|c|}
\hline $\begin{array}{c}\text { Skala } \\
\text { penilaian }\end{array}$ & $\begin{array}{c}\text { Nilai } \\
\text { aktivitas } \\
(\%)\end{array}$ & Deskripsi \\
\hline 4 & $76-100$ & $\begin{array}{l}\text { Sangat } \\
\text { baik }\end{array}$ \\
\hline 3 & $51-75$ & Baik \\
\hline 2 & $26-50$ & $\begin{array}{c}\text { Cukup } \\
\text { baik }\end{array}$ \\
\hline 1 & $\leq 25$ & $\begin{array}{c}\text { Kurang } \\
\text { baik }\end{array}$ \\
\hline
\end{tabular}

Sumber: Trianto, 2010 (dalam

Nurpratiwi,2015: 4)

Kriteria penilaian tersebut menjadi tolok ukur dalam analisis data pada rumusan masalah satu dan dua yaitu analisis data aktivitas belajar siswa sebelum diberi perlakuan dan sesudah diberi perlakuan dengan model Numbered Head Together.

Untuk menjawab rumusan masalah tiga yang merupakan hipotesis tindakan penelitian ini dilakukan dengan langkah-langkah sebagai berikut: a) Uji Normalitas (dengan SPSS 17.0); b) Pengujian Korelasi Pearson Product Moment (dengan SPSS 17.0); c) Uji t dengan rumus sebagai berikut (Siregar, 2017: 253):

$$
\mathrm{t}_{\text {hitung }}=\frac{r \sqrt{n-2}}{\sqrt{1-(r)^{2}}}
$$

Kesimpulan dibuat setelah menghitung hipotesis dengan uji t dan dengan kaidah pengujian sebagai berikut (Siregar, 2017: 253): 
Jika, $-\mathrm{t}_{\text {tabel }} \leq \mathrm{t}_{\text {hitung }} \leq \mathrm{t}_{\text {tabel }}$, maka $\mathrm{H}_{0}$ diterima

Jika, $\mathrm{t}_{\text {hitung }}>\mathrm{t}_{\text {tabel }}$, maka $\mathrm{H}_{0}$ ditolak

\section{HASIL PENELITIAN DAN PEMBAHASAN}

\section{Hasil Penelitian}

Penilaian terhadap aspek aktivitas yang diamati dilakukan selama proses pembelajaran berlangsung. Aspek-aspek yang dinilai adalah aktivitas visual, aktivitas lisan, aktivitas mendengarkan, aktivitas menulis, dan aktivitas emosional.

Kegiatan observasi aktivitas belajar siswa sebelum menggunakan model Numbered Head Together dilaksanakan pada tanggal 10 November 2018 dan diperoleh hasil sebagai berikut:

Tabel 2. Data hasil pretest aktivitas belajar siswa

\begin{tabular}{lccc}
\hline $\begin{array}{l}\text { Aspek Yang } \\
\text { Diamati }\end{array}$ & $\begin{array}{c}\text { Jum } \\
\text { lah }\end{array}$ & $\begin{array}{c}\text { Nilai } \\
(\%)\end{array}$ & Kriteria \\
\hline $\begin{array}{l}\text { Aktivitas } \\
\text { Visual }\end{array}$ & 109 & 56,77 & Baik \\
$\begin{array}{l}\text { Aktivitas } \\
\text { Lisan }\end{array}$ & 91 & 47,40 & $\begin{array}{c}\text { Cukup } \\
\text { Baik }\end{array}$ \\
$\begin{array}{l}\text { Aktivitas } \\
\text { Mendengark } \\
\text { an }\end{array}$ & 99 & 51,56 & Baik \\
$\begin{array}{l}\text { Aktivitas } \\
\text { Menulis }\end{array}$ & 96 & 50,00 & $\begin{array}{c}\text { Cukup } \\
\text { Bktivitas }\end{array}$ \\
$\begin{array}{l}\text { Emosional } \\
\text { Jumlah }\end{array}$ & 112 & 58,33 & Baik \\
\hline \multicolumn{1}{c}{ Nilai rata-rata } & 52,81 & Baik \\
\hline \multicolumn{1}{c}{ Berdasarkan } & data & tersebut
\end{tabular}

diketahui bahwa aktivitas belajar siswa sebelum menggunakan model Numbered Head Together sebesar $52,81 \%$ dengan kategori baik. Dan setiap aspek memiliki presentase yang berbeda-beda. Aktivitas visual siswa sebesar $56,77 \%$ dengan kategori baik, aktivitas lisan sebesar $47,40 \%$ dengan kategori cukup baik,aktivitas mendengarkan sebesar 51,56\% dengan kategori baik, aktivitas menulis sebesar $50,00 \%$ dengan kategori cukup baik, dan aktivitas emosional sebesar $58,33 \%$ dengan kategori baik.

Kegiatan observasi terhadap aktivitas belajar siswa dengan menggunakan model Numbered Head Together dilaksanakan pada tanggal 12 November 2018 dan diperoleh hasil sebagai berikut:

Tabel 3. Data hasil posttest aktivitas belajar siswa

\begin{tabular}{|c|c|c|c|}
\hline $\begin{array}{c}\text { Aspek Yang } \\
\text { Diamati }\end{array}$ & $\begin{array}{l}\text { Jum } \\
\text { lah }\end{array}$ & $\begin{array}{l}\text { Nilai } \\
(\%)\end{array}$ & Kriteria \\
\hline $\begin{array}{l}\text { Aktivitas } \\
\text { Visual }\end{array}$ & 166 & 86,45 & $\begin{array}{c}\text { Sangat } \\
\text { baik }\end{array}$ \\
\hline $\begin{array}{l}\text { Aktivitas } \\
\text { Lisan }\end{array}$ & 128 & 66,67 & Baik \\
\hline $\begin{array}{l}\text { Aktivitas } \\
\text { Mendengark } \\
\text { an }\end{array}$ & 149 & 77,60 & $\begin{array}{c}\text { Sangat } \\
\text { baik }\end{array}$ \\
\hline $\begin{array}{l}\text { Aktivitas } \\
\text { Menulis }\end{array}$ & 135 & 70,31 & Baik \\
\hline $\begin{array}{l}\text { Aktivitas } \\
\text { Emosional }\end{array}$ & 154 & 80,21 & $\begin{array}{c}\text { Sangat } \\
\text { baik }\end{array}$ \\
\hline \multicolumn{2}{|l|}{ Jumlah } & $\begin{array}{c}381,2 \\
5\end{array}$ & 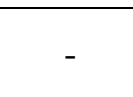 \\
\hline \multicolumn{2}{|c|}{ Nilai Rata-rata(\%) } & 76,25 & $\begin{array}{c}\text { Sangat } \\
\text { Baik }\end{array}$ \\
\hline
\end{tabular}


Berdasarkan data yang diperoleh tersebut diketahui bahwa aktivitas belajar siswa setelah menggunakan model Numbered Head Together sebesar 76,25\% dengan kategori sangat baik. Dan diperoleh nilai aktivitas visual $86,45 \%$ dengan kategori sangat baik, aktivitas lisan $66,67 \%$ dengan kategori baik, aktivitas mendengarkan $77,60 \%$ dengan kategori sangat baik, aktivitas menulis $70,31 \%$ dengan kategori baik, dan aktivitas emosional $80,21 \%$ dengan kategori sangat baik. dari hasil tersebut dapat diketahui bahwa aktivitas belajar pendidikan kewarganegaraan siswa kelas III SDN 01 Noyan meningkat setelah diberikan perlakuan menggunakan model Numbered Head Together.

Hasil data pretest dan posttest aktivitas belajar siswa tersebut kemudian dianalisis untuk melihat apakah ada pengaruh model Numbered Head Together terhadap aktivitas belajar siswa pada pendidikan kewarganegaraan. Berikut adalah data aktivitas belajar siswa sebelum dan sesudah diberi perlakuan:
Tabel 4. Data Hasil Pretest Dan

Posttest Aktivitas Belajar Siswa

\begin{tabular}{|c|c|c|c|}
\hline $\begin{array}{l}\text { Aspek } \\
\text { yang } \\
\text { diamati }\end{array}$ & $\begin{array}{l}\text { Pre- } \\
\text { test } \\
(\%)\end{array}$ & $\begin{array}{l}\text { Post- } \\
\text { test } \\
(\%)\end{array}$ & $\begin{array}{c}\text { Seli- } \\
\text { sih } \\
\text { nilai } \\
(\%)\end{array}$ \\
\hline $\begin{array}{l}\text { Aktivitas } \\
\text { Visual }\end{array}$ & 56,77 & 86,45 & 29,68 \\
\hline $\begin{array}{l}\text { Aktivitas } \\
\text { Lisan }\end{array}$ & 47,40 & 66,67 & 19,27 \\
\hline $\begin{array}{l}\text { Aktivitas } \\
\text { Mendenga } \\
\text { rkan }\end{array}$ & 51,56 & 77,60 & 26,04 \\
\hline $\begin{array}{l}\text { Aktivitas } \\
\text { Menulis }\end{array}$ & 50,00 & 70,31 & 20,31 \\
\hline $\begin{array}{l}\text { Aktivitas } \\
\text { Emosional }\end{array}$ & 58,33 & 80,21 & 21,88 \\
\hline Jumlah & $\begin{array}{c}264,0 \\
6\end{array}$ & 381,24 & $\begin{array}{c}117,1 \\
8\end{array}$ \\
\hline Nilai & 52,81 & 76,25 & 23,43 \\
\hline Kriteria & Baik & $\begin{array}{c}\text { Sangat } \\
\text { baik }\end{array}$ & - \\
\hline
\end{tabular}

diketahui aktivitas belajar siswa sebelum menggunakan model Numbered Head Together sebesar $52,81 \%$ dan sesudah menggunakan model Numbered Head Together sebesar $76,25 \%$ dengan selisih nilai sebesar $23,43 \%$. Selisih nilai tersebut menunjukan bahwa terdapat perbedaan aktivitas belajar siswa sebelum dan sesudah diberi perlakuan.

Pengujian hipotesis dilakukan melalui langkah-langkah yaitu diawali dengan uji normalitas data melalui SPSS 17.0: 
Tabel 5. Uji Kolmogorov-smirnov

\begin{tabular}{llrr}
\hline $\begin{array}{c}\text { One-Sample Kolmogorov-Smirnov } \\
\text { Test }\end{array}$ \\
\hline & & \multicolumn{2}{c}{ Posttes } \\
& & Pretest & \multicolumn{1}{c}{$\mathrm{t}$} \\
\hline $\mathrm{N}$ & 24 & 24 \\
Normal & Mean & 52.791 & 76.250 \\
Parameters ${ }^{\mathrm{a}, \mathrm{b}}$ & & 7 & 0 \\
& & 3.8558 & 3.7590 \\
& Std. & 7 & 5 \\
& Deviatio & &
\end{tabular}

Most Extreme Absolute $\quad .280 \quad .161$

Differences Positive $\quad .280 \quad .161$

Negative $\quad-.151 \quad-.130$

$\begin{array}{lll}\text { Kolmogorov-Smirnov Z } & 1.372 \quad .791\end{array}$
Asymp. Sig. (2-tailed)

.046

a. Test distribution is Normal.

b. Calculated from data.

Sumber: SPSS 17.0

Berdasaran hasil uji normalitas tersebut dapat diketahui bahwa data berdistribusi normal.

Pengujian selanjutnya untuk menghitung korelasi pearson product moment dengan menggunakan SPSS 17.0 melalui uji correlations Bivariat.

Tabel 6. Uji Correlation Bivariat

\begin{tabular}{llrr}
\hline \multicolumn{4}{c}{ Correlations } \\
\hline & & PRE- & POST- \\
& & TEST & TEST \\
\hline PRETEST & Pearson Correlation & 1 & $.495^{*}$ \\
& Sig. (2-tailed) & & .014 \\
& $\mathrm{~N}$ & 24 & 24 \\
\hline POSTTEST & Pearson Correlation & $.495^{*}$ & 1 \\
& Sig. (2-tailed) & .014 & \\
& $\mathrm{~N}$ & 24 & 24 \\
\hline
\end{tabular}

*. Correlation is significant at the 0.05 level (2-tailed).

Sumber: SPSS 17.0

\begin{abstract}
Berdasarkan hasil signifikan
yang didapat sebesar 0,495 menunjukan nilai yang signifikan berdasarkan taraf signifikansi 0,05
\end{abstract} (Siregar, 2017: 515).Selanjutnya perhitungan hipotesis melalui uji $\mathrm{t}$ sebagai berikut:

$$
\begin{gathered}
\text { thitung }=\frac{r \sqrt{n-2}}{\sqrt{1-(r)^{2}}} \\
\text { thitung }=\frac{0,495 \sqrt{24-2}}{\sqrt{1-(0,495)^{2}}}
\end{gathered}
$$

$$
\begin{gathered}
t \text { hitung }=\frac{0,495 \sqrt{22}}{\sqrt{1-0,245}} \\
t \text { hitung }=\frac{(0,495)(4,690)}{\sqrt{0,755}}
\end{gathered}
$$

$$
\begin{aligned}
& t \text { hitung }=\frac{2,321}{0,868} \\
& t \text { hitung }=2,673
\end{aligned}
$$

Berdasarkan hasil dari perhitungan korelasi pearson product moment didapat hasil signifikan 
sebesar 0,495 sehingga didapat nilai $t_{\text {hitung }}$ sebesar 2,673 melalui uji t.

\section{Pembahasan}

Berdasarkan hasil observasi diperoleh aktivitas belajar siswa sebelum diberi perlakuan sebesar $52,81 \%$ dengan kategori baik. Dan hasil dari setiap aspek yaitu; a) aktivitas visual sebesar $56,77 \%$ kategori baik artinya aktivitas belajar siswa dalam melihat gambar, mengamati dan memperhatikan orang lain sudah baik; b) aktivitas lisan sebesar 47,60\% kategori cukup baik artinya aktivitas belajar siswa dalam mengajukan pertanyaan dan mengemukakan pendapat sudah cukup baik; c) aktivitas mendengarkan $51,56 \%$ kategori baik artinya, aktivitas belajar siswa dalam hal mendengarkan materi ajar, dan percakapan atau diskusi kelompok sudah baik; d) aktivitas menulis $50,00 \%$ kategori cukup baik artinya, aktivitas belajar siswa dalam mencatat hal-hal yang telah disampaikan guru dan menulis hasil diskusi sudah cukup baik; dan e) aktivitas emosional 58,33\% kategori baik artinya, aktivitas belajar siswa dalam hal merasa gembira, berani, dan tenang sudah baik. Dan dapat diamati juga bahwa masih ada beberapa aspek yang mendapatkan nilai cukup baik, yaitu aktivitas lisan dan menulis artinya masih ada siswa yang belum berpartisipasi aktif dalam bertanya dan mengutarakan pendapat, dan masih kurang dalam hal mengerjakan atau menulis hal-hal yang telah disampaikan guru dan siswa. Sedangkan jika dilihat dari data individu siswa diketahui bahwa dari 24 siswa kelas III terdapat 16 siswa dengan kategori baik, dan 8 siswa dengan kategori cukup baik.

Berdasarkan hasil tersebut dapat diketahui aktivitas lisan dan menulis siswa kategori cukup baik sehingga dirasa perlu untuk ditingkatkan.Aktivitas lisan erat hubungannya dengan aktivitas berbicara. Salimah (dalam Lesi, 2017: 50) menyebutkan bahwa keterempilan berbicara adalah suatu ketentuan yang dimiliki seseorang dalam mengucapkan bunyi atau kata-kata, mengekspresikan, menyampaikan pikiran, gagasan, serta perasaan kepada orang lain secara lisan. Sehingga dibutuhkan keefektivan siswa dalam belajar.Prayitno (dalam Silya, 2013: 2) mengemukanan bahwa keefektifan siswa dalam belajar, tampak apabila siswa memberikan komentar terhadap materi yang dibahas, bertanya tentang hal-hal yang belum mereka pahami, 
dan berusaha dengan berani menjawab pertanyaan.Menilai dari pendapat tersebut menunjukan bahwa aktivitas lisan mempengaruhi aktivitas belajar siswa sehingga perlu untuk ditingkatkan.

Kegiatan observasi terhadap aktivitas belajar siswa menggunakan model Numbered Head Together dilakukan pada senin 12 november 2018. Berdasarkan hasil yang diperoleh, diketahui bahwa terjadi peningkatan sebesar $76,25 \%$ dengan kategori sangat baik dari aktivitas belajar siswa sebelumnya sebesar $52,81 \%$. Dan hasil dari setiap aspek yaitu; a) aktivitas visual sebesar $84,46 \%$ kategori sangat baik artinya aktivitas siswa dalam melihat gambar, mengamati dan memperhatikan orang lain sudah sangat baik dari sebelumnya, siswa aktif dalam melihat dan mengamati gambar yang diberikan guru, dan lebih fokus dalam memperhatikan kegiatan guru dan siswa dalam presentasi di kelas, b) aktivitas lisan sebesar $66,67 \%$ kategori baik artinya aktivitas belajar siswa dalam mengajukan pertanyaan dan mengemukakan pendapat sudah lebih baik dari sebelumnya, siswa sudah aktif berpartisipasi dalam bertanya dan mengemukakan pendapat; c) aktivitas mendengarkan sebesar $\quad 77,60 \%$ kategori sangat baik artinya aktivitas belajar siswa dalam mendengarkan materi ajar, dan percakapan atau diskusi dalam kelompok sudah sangat baik, siswa lebih fokus dalam menyimak setiap penjelasan yang disampaikan guru dan menyimak dalam percakapan atau kegiatan diskusi kelompok yang dilakukan; d) aktivitas menulis sebesar 70,31\% kategori baik, artinya aktivitas belajar siswa dalam mencatat hal-hal yang telah disampaikan dan menulis hasil diskusi sudah baik, siswa mulai aktif mencatat materi ajar yang telah disampaikan oleh guru atau yang telah dituliskan dipapan tulis, dan aktif dalam mencatat hasil diskusi kelompok dan pendapat dari presentasi yang dilakukan oleh kelompok siswa, e) dan aktivitas emosional sebesar $80,21 \%$ kategori sangat baik, artinya bahwa aktivitas siswa dalam merasa gembira, berani dan tenang sudah sangat baik, siswa merasa antusias dan senang selama mengikuti pembelajaran dengan model Number Head Together dan siswa mulai lebih merasa berani dalam mengajukan pertanyaan dan mengemukakan pendapat dan tenang dalam menjawab dan melakukan presentasi diskusi kelompok di depan 
kelas. Sedangkan jika dilihat dari data aktivitas individu siswa diketahui bahwa dari 24 siswa kelas III SDN 01 Noyan terdapat 12 siswa dengan kategori baik, dan 12 siswa dengan kategori sangat baik.

Berdasarkan hasil tersebut menunjukan bahwa aktivitas belajar siswa pada pendidikan kewarganegaraan sangat baik setelah diterapkan model Numbered Head Together. Pentingnya aktivitas belajar siswa agar proses pembelajaran dapat berjalan dengan baik dan siswa dapat mendapatkan pengalaman melalui aktivitas-aktivitas yang dilakukan dalam kegiatan pembelajaran. Usman (dalam Lesi, 2017: 46) menyatakan bahwa aktivitas siswa sangat diperlukan dalam kegiatan belajar mengajar, sebab siswa sebagai subjek didik adalah yang merencanakan, dan siswa sendiri yang melaksanakan.

Pada pembelajaran pendidikan kewarganegaraan menggunakan Numbered Head Together ini aktivitas siswa meningkat hal itu karena model tersebut dapat mempengaruhi pola interaksi siswa dan sebagai alternative terhadap struktur kelas tradisional (Trianto, 2011: 82).

Berikut adalah hasil pretest dan posttest aktivitas belajar siswa setelah dikonversikan ke dalam diagram batang:

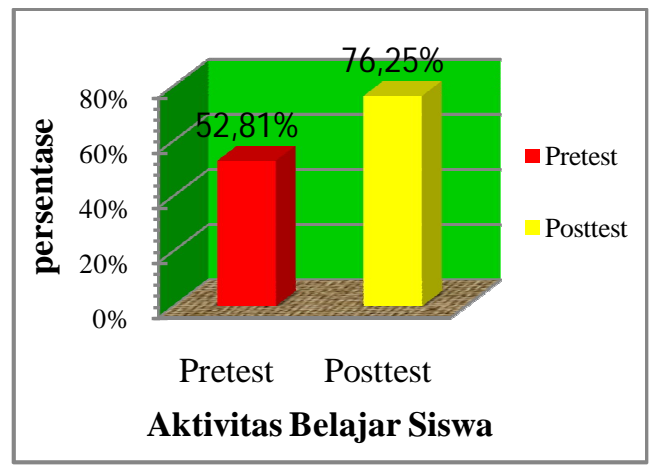

Gambar 1. Grafik rata-rata pretest dan posttest aktivitas belajar siswa

Berdasarkan diagram tersebut terlihat bahwa terdapat perbedaan antara aktivitas belajar siswa sebelum dan sesudah diberi perlakuan dengan model Numbered Head Together, dan dapat dihitung selisih nilai sebesar 23,43\%. Selisih nilai tersebut menunjukan bahwa ada pengaruh penggunaan model Numbered Head Together terhadap aktivitas belajar pendidikan kewarganegaraan.

Sedangkan berdasarkan hasil perhitungan hipotesis melalui uji $\mathrm{t}$ diperoleh $t_{\text {hitung }}$ sebesar 2,673 dengan taraf signifikan 0,05 dan taraf kepercayaan 95\%. Hasil tersebut kemudian dibandingkan dengan $t_{\text {tabel }}$ untuk menjawab hipotesis yang telah dibuat. Nilai distribusi $t_{\text {tabel }}$ dengan signifikansi $\quad 0,05$ sebesar 2,064 (Siregar, 2017: 514). Berdasarkan kaidah pengujian yang telah dibuat maka dapat disimpulkan bahwa $t_{\text {hitung }}>$ 
$\mathrm{t}$ tabel dengan 2,672>2,064, Hasil tersebut menunjukan bahwa $\mathrm{H}_{0}$ ditolak dan $\mathrm{H}_{\mathrm{a}}$ diterima. Artinya bahwa ada pengaruh penggunaan model Numbered Head Together Terhadap Aktivitas Belajar pendidikan kewarganegaraan kelas III SDN 01 Noyan.

Pelakasanaan penelitian dengan menggunakan model Numbered Head Together ini juga ditemukan kelebihan dan kelemahan lain berdasarkan pengamatan yang dilakukan selama proses pembelajaran berlangsung. Kelebihan model Numbered Head Together berdasarkan temuan dalam penelitian ini yaitu siswa menjadi lebih antusias dalam mengikuti pembelajaran, siswa terlihat senang dan merasa gembira sehingga siswa berpartisipasi aktif dalam setiap proses pembelajaran. Sedangkan kelemahan yang ditemukan dalam penelitian ini yaitu kurangnya waktu yang diperlukan untuk pelaksanaan pembelajaran dengan model Numbered Head Together sehingga dirasa kurang maksimal, dan jumlah siswa yang terlalu banyak juga dapat mempengaruhi proses pembelajaran dengan model ini, sehingga akan memerlukan banyak waktu dalam persiapan dan pelaksanaannya.

\section{SIMPULAN}

Berdasarkan hasil penelitian yang diperoleh melalui pengolahan dan analisis data yang telah diuraikan, maka dapat disimpulkan sebagai berikut: 1) Aktivitas belajar asiswa sebelum menggunakan model Numbered Head Together sebesar $52,81 \%$ dengan kategori baik dan dengan aspek aktivitas visual sebesar $56,77 \%$ dengan kategori baik, aktivitas lisan sebesar 47,40\% dengan kategori cukup baik, aktivitas mendengarkan sebesar 51,56\% dengan kategori baik, aktivitas menulis sebesar 50,00\% dengan kategori cukup baik, dan aktivitas emosional sebesar 58,33\% dengan kategori baik; 2) aktivitas belajar siswa setelah menggunakan model Numbered Head Together sebesar 76,25\% dengan kategori sangat baik, dan dengan aktivitas visual sebesar 86, 46\% dengan kategori sangat baik, aktivitas lisan sebesar $66,67 \%$ dengan kategori baik, aktivitas mendengarkan sebesar $77,60 \%$ dengan kategori sangat baik, aktivitas menulis sebesar 70,31\% dengan kategori baik, dan aktivitas emosional sebesar 80,21\% dengan kategori sangat baik; 3) Penggunaan model Numbered Head Together berpengaruh terhadap aktivitas belajar siswa pada pendidikan 
kewarganegaraan kelas III SDN 01 Noyan, hal tersebut ditunjukan dari selisih nilai aktivitas belajar siswa setelah diberi perlakuan dengan model Numbered Head Together sebesar $23,43 \%$. Sedangkan berdasarkan hasil uji hipotesis diketahui bahwa melalui uji t dengan taraf signifikansi 0,05 dan taraf kepercayaan $95 \%$ diperoleh nilai $t_{\text {hitung }}>t_{\text {tabel}}$, dengan 2,673>2,064, hasil tersebut menunjukan bahwa $\mathrm{H}_{0}$ ditolak dan $\mathrm{H}_{\mathrm{a}}$ diterima. Artinya ada pengaruh penggunaan model Numbered Head Together Terhadap Aktivitas Belajar; 4) terdapat perbedaan aktivitas belajar siswa sete;ah diberi perlakuan dengan menggunakan model Numbered Head Together, siswa menjadi lebih aktif mengikuti pembelajaran, fokus dalam mendengarkan dan memperhatikan guru dan diskusi kelompok, berani dalam bertanya dan menjawab pertanyaan, dan memiliki antusias dalam mengikuti pembelajaran.

\section{DAFTAR PUSTAKA}

Fitri, E. 2014. "Perbandingan Model Pembelajaran Kooperatif Numbered Head Together (NHT) Dengan Konvensional Terhadap Hasil Belajar Siswa Pada Materi Ketenagakerjaan Di Kelas VIII SMP Negeri 2
Jangka". Jurnal Sains Ekonomi

Dan Edukasi. Vol. 11, No. 2 November 2014

Hamalik, O. 2017. Proses Belajar Mengajar. Jakarta: Bumi Aksara Maryanti, S. 2013. Hubungan Antara Keterampilan Komunikasi Dengan Aktivitas Belajar Siswa. Bimbingan Dan Konseling. FKIP-Universitas Negeri Padang Nurpratiwi, R. T. 2015. "Peningkatan Aktivitas Dan Prestasi Belajar Siswa Melalui Metode Picture And Picture Dengan Media Audio Visual Pada Mata Pelajaran Geografi Di Kelas XI IPS 2 SMA Negeri 01 Bantar Kawung”. FKIP-Unuversitas Muhammadiyah Purwokerto. Vol.IV

Sari, L. W. "Aktivitas Belajar Siswa Pada Materi Struktur Atom Kelas X MIA Sekolah Menengah Atas Negeri 4 Pontianak". Jurnal Ilmiah. Pendidikan Kimia FKIPUniversitas Muhammadiyah Pontianak. Vol. 5, No. 1, Februari 2017

Sugiyono. 2013. Metode Penelitian Pendidikan. Bandung: Alfabeta Suprijono, Agus. 2013. Cooperative Learning. Jakarta: Pustaka Pelajar 
Jurnal Pendidikan Dasar, 7 (1), Juni 2019

Tim Redaksi. 2007. Kamus Besar

Bahasa Indonesia. Jakarta: Balai Pustaka
Trianto. 2011. Mendesain Model Pembelajaran Inovatif-Progresif. Jakarta: Kencana

79| J P D, p - I S S N : 2252 - 8156 , e - I S S N : 2579 - 3993 